\title{
Meningkatkan Aktivitas dan Prestasi Belajar Siswa melalui Metode Index Card Match padaa Materi Pokok Persegi dan Persegi Panjang Kelas VII-b SMP Negeri 1 Wera Tahun Pelajaran 2019/2020
}

\author{
Dusalan $^{1 *}$, Mikrayanti', Basrin ${ }^{2}$, Rista Salma Jauhari², M. Furqan ${ }^{2}$ \\ ${ }^{1}$ Dosen Prodi Pendidikan Matematika, STKIP Bima, Kota Bima, Indonesia \\ ${ }^{2}$ Mahasiswa Prodi Pendidikan Matematika, STKIP Bima, Kota Bima, Indonesia \\ *Coresponding Author: dusalan_mat@stkipbima.ac.id
}

\begin{abstract}
Abstrak: Penerapan suatu metode dalaam pembelajarn memiliki peranan yaang sangat penting. Jika tidak sesuai maka siswa tidak akan belajar sebaik-baiknya karena tidak adanya daya tarik baginya. Dalaam pembelajarn guru dituntut memperhatikan metode mengajar yaang digunakan. Meningkatnya prestasi belajar siswa tergantung padaa kemampuan guru dalaam memilih metode pengajaran yaang sesuai dengn bahan yaang diajarkan. Salah satu upaya yaang dilakukan adalah mencari metode mengajar yaang mampu mengajak siswa lebih aktif dalaam kegiatan belajar serta melatih siswa untuk banyak belajar sendiri. Mencermati hal tersebut di atas, sudah saatnya untuk diadakan pembaharuan, inovasi ataupun gerakan perubahan kearah pencapaian tujuan pendidikan di atas. Pembelajarn matematika hendaknya menggunakan metode yaang sesuai dengn karakter siswa yaang dapat mengoptimalkan potensi siswa. (Penelitian ini bertujuan untuk meningkatkan Aktivitas belajar siswa kelas VII B SMP Negeri 1 Wera dalaam pembelajarn matematika padaa materi Persegi dan persegi panjang dengn metode index card match dan meningkatkan Prestasi belajar siswa kelas VII B SMP Negeri 1 Wera, padaa materi pokok Persegi dan persegi panjang dengn metode index card match Tahun Pelajaran 2019/2020). Adapun tempat penelitian dilakukan di SMP Negeri 1 Wera Bima. Jenis penelitian ini adalah penelitian tindakan kelas (PTK) tentang metode index card match. Adapun pendekatan yaang digunakan dalaam penelitian ini adalah pendekatan kualitatif dan pendekatan kuantitatif. Penelitian ini terdiri darii dua siklus, hasil penelitian menunjukkan bahwa darii siklus ke siklus mengalami peningkatan. Hal ini terbukti darii persentase ketuntasan klasikal belajar siswa padaa siklus I mencapai 75\% dan nilai rata-rata sebesar 61,08 dengn kategori siswa cukup aktif sedangkan padaa siklus II sebesar 91,67\% dan nilai rata-rata sebesar 79,58 dengn kategori siswa aktif, terlihat bahwa persentase ketuntasan belajar siswa padaa siklus II sudah memenuhi kriteria yaang ditetapkan yakni $\geq 85 \%$. Darii data yaang diperoleh maka dapat disimpulkan bahwa penerapan metode index card match dapat meningkatkan aktifitas dan prestasi belajar siswa kelas VII B SMP Negeri 1 Wera padaa materi pokok Persegi dan persegi panjang tergolong aktif.
\end{abstract}

Kata Kunci: Metode Index Card Match; Aktivitas dan Prestasi Belajar; Persegi dan Persegi Panjang

\section{PENDAHULUAN}

Pendidikan padaa dasarnya merupakan proses untuk membantu manusia dalaam mengembangkan dirinya sehingga mampu menghadapi setiap perubahan yaang terjadi. Dalaam rangka pembangunan manusia seutuhnya, pembangunan dibidang pendidikan merupakan sarana dan wahana yaang sangat baik di dalaam pembinaan Sumber Daya Manusia. Oleh karena itu, bidang pendidikan perlu mendapat perhatian, penanganan, dan prioritas secara intensif baik oleh pemerintah, keluarga, dan pegelola pendidikan khususnya.

Untuk mendapatkan pendidikan yaang berkualitas tidak terlepas darii peran seorang guru dalaam proses pembelajarn. Guru dituntut mampu menciptakan situasi pembelajarn yaang kondusif, yaitu pembelajarn yaang aktif, kreatif, inovatif, efektif dan menyenangkan dalaam proses kegitan pembelajarn. Untuk menciptakan suasana 
tersebut tentunya tidak mudah. Ada banyak faktor yaang akan menghambat penciptaan suasana pembelajarn tersebut. Faktor penghambat internal yaang berasal darii siswa itu sendiri yaitu ketidaksiapan siswa dalaam menerima pelajaran dan kurangnya minat serta motivasi terhadap pelajaran tersebut kurang, sehingga berdampak padaa hasil belajarnya. Sedangkan faktor eksternal berasal darii guru sendiri yaang kurang inovatif, sehingga dalaam kegiatan pembelajarn cenderung monoton dan menjenuhkan. Hal ini akan membuat siswa merasa bosan dalaam kegiatan pembelajarn.

Pelajaran matematika sebagai salah satu materi ajar yaang berkaitan dengn mempelajari ide-ide atau konsep yaang bersifat abstrak, tentunya tidak luput darii kondisi yaang penuh dengn problematika baik darii segi internal maupun eksternal. Banyak peserta didik beranggapan bahwa Matematika merupakan materi ajar yaang sulit, sehingga kurang berminat terhadap Matematika (http://www.scribd. 2010/com). Hal ini berdampak padaa kurangya penguasaan konsep-konsep dalaam Matematika. Idealnya, guru juga tidak harus mengajarkan konsep-konsep, teori-teori dalaam bentuk kognitif tingkat rendah yaang hanya mengedepankan kemampuan menghafal saja tetapi guru membimbing siswa untuk menganalisa konsep dan memberikan kesempatan kepadaa siswa atau peserta didik untuk berinteraksi langsung dengn obyek.

Aspek-aspek pembelajarn Matematika mencakup proses belajar mengajar dan pemikiran yaang kreatif. Dalaam kegiatan belajar mengajar di sekolah, sering dijumpai berbagai permasalahan. Kesalahan yaang dilakukan siswa tidak hanya besumber padaa kemampuan siswa yaang kurang, tetapi ada faktor lain yaang ikut menentukan keberhasilan siswa dalaam belajar matematika, salah satunya adalah metode pembelajarn yaang dipilih guru sebagai pengajar. Permasalahan lain yaang masih sering muncul adalah penggunaan metode pembelajarn oleh guru yaang kurang tepat. Guru kurang bervariasi dalaam mengajar. Bahkan proses pembelajarn masih di dominasi oleh guru.

Berdasarkan pengamatan sementara yaang dilakukan oleh peneliti di SMP Negeri 1 Wera. Banyak dijumpai siswa yaang masih memiliki nilai rendah, terutama Mata Pelajaran Matematika. Hasil belajar Matematika yaang dicapai siswa masih banyak yaang berada di bawah standar yaang ditetapkan, yaitu sebagai berikut:

Tabel 1. Data nilai semester I siswa kelas VII padaa mata pelajaran Matematika SMP Negeri 1 Wera Kecamatan Wera tahun pelajaran 2019/2020

\begin{tabular}{|l|l|l|l|l|l|}
\hline No. & \multicolumn{1}{|c|}{ Kelas } & \multicolumn{1}{c|}{$\begin{array}{c}\text { Nilai } \\
\text { rata-rata }\end{array}$} & \multicolumn{1}{|c|}{ KKM } & Ketuntasan & Keterangan \\
\hline 1 & Kelas VII A & 65,5 & 60 & $80 \%$ & $\begin{array}{l}\text { Ketuntasan } \\
\text { berdasarkan } \\
\text { hasil remidi I } \\
\text { dan II. }\end{array}$ \\
\hline 2 & Kelas VII B & 64,5 & 60 & $81 \%$ & \\
\hline
\end{tabular}

Dengn melihat rendahnya nilai rata-rata siswa semester gasal padaa mata pelajaran matematika tersebut, maka penelitian ini perlu dilakukan di kelas VII-B SMP Negeri 1 Wera tahun pelajaran 2019/2020. Selain itu berdasarkan hasil wawancara dengn guru matematika kelas VII SMP Negeri 1 Wera tahun pelajaran 2019/2020, bahwa selain disebabkan oleh rendahnya hasil ulangan harian, ada juga beberapa kendala yaang dihadapi padaa proses belajar mengajar berlangsung, yaitu kurang aktifnya siswa bertanya, siswa kurang mandiri dalaam mengerjakan latihan, 
motivasi siswa kurang dalaam mempelajari matematika, kebanyakan siswa kurang memahami konsep dasar, dan kenakalan siswa.

Padaa umumnya, metode pembelajarn yaang dikembangkan guru Matematika dalaam kegiatan mengajar adalah metode pembelajarn konvensional yaang lebih banyak mengandalkan ceramah. Dimana guru lebih memfokuskan diri padaa upaya pemindahan pengetahuan ke dalaam diri siswa tanpa memperhatikan bahwa ketika siswa memasuki kelas, siswa mempunyai bekal kemampuan dan pengetahuan yaang tidak sama. Siswa hanya ditempatkan sebagai objek sehingga siswa menjadi pasif dan kurang terangsang aktivitas belajar. Proses pembelajarn yaang berpusat padaa guru tersebut, dimana guru sebagai penyampaian materi atau penceramah dan siswa sebagai pendengar mempunyai kelamahan yaitu siswa cenderung ramai, mengantuk, tidak ada pertanyaan darii siswa serta siswa juga tidak mampu menjawab dengn sempurna pertanyaan yaang diberikan guru.

Untuk mengatasi masalah yaang telah dikemukakan di atas salah satu cara adalah dengn menerapkan strategi pembelajarn untuk meningkatkan aktivitas dan prestasi belajar siswa diantaranya melalui penerapan metode Index Card Match. Metode Index Card Match dapat menjadi alternatif dalaam menciptakan pembelajarn yaang menyenangkan.

Metode Index Card Match merupakan strategi yaang sangat menyenangkan yaang digunakan untuk mengulangi materi yaang telah diberikan sebelumnya. Namun demikian, materi baru pun tetap bisa diajarkan dengn strategi ini dengn catatan, siswa diberi tugas mempelajari topik yaang akan diajarkan terlebih dahulu, sehingga ketika masuk kelas mereka sudah memiliki bekal pengetahuan (Suprijono, A., 2010:120).

Berdasarkan uraian di atas, penulis ingin melakukan penelitian dengn judul Meningkatkan Aktivitas Dan Prestasi Belajar Siswa Melalui Metode Index Card Match Padaa Materi Pokok Persegi Dan Persegi Panjang Kelas VIIB SMP Negeri 1 Wera Tahun Pelajaran 2019/2020.

\section{KAJIAN TEORI}

\section{Aktivitas Belajar}

Aktivitas adalah kemampuan untuk membuat kombinasi-kombinasi baru, atau melihat hubungan-hubungan baru antara unsur, data, atau hal-hal yaang sudah ada sebelumnya. Aktivitas terletak padaa kemampuan untuk melihat situasi antara hal-hal atau obyek-obyek yaang sebelumnya tidak ada atau tidak tampak hubungannya. Kreativitas dapat muncul dalaam semua bidang kegiatan manusia, tidak terbatas dalaam bidang seni, ilmu pengetahuan dan teknologi serta tidak terbatas padaa tingkat usia, jenis kelamin, suku, bangsa atau kebudayaan tertentu (Setiawan, 2000).

Aktivitas ialah kesanggupan seseorang untuk menemukan sesuatu yaang baru dengn jalan mempergunakan daya khayal, fantasi atau imajinasi. Kreativitas dapat dilakukan dalaam berbagai bentuk kegiatan baik dalaam bentuk kegiatan fisik maupun non fasik (Pemikiran). Menurut Setiawan (2000) kemampuan dalaam aktivitas yaang cepat dan efisien melibatkan berbagai macam keterampilan dan kemampuan sebagai berikut: 
a. Kemampuan menduga (Predictive Skills) yaitu kemampuan untuk memprediksikan isi yaang tertuang dalaam sebuah pokok permasalahan secara cepat dan tepat.

b. Keterampilan menganalisa informasi spesifik (Analyze specific information). Artinya gagasan-gagasan yaang disampaikan secara khusus dalaam pokok permasalahan dapat dikuasai.

c. Keterampilan memahami gambaran umum, artinya gambaran secara umum dalaam pokok permasalahan dapat dipahami.

d. Keterampilan menyimpulkan sikap dan pendapat (Informing opinion and attitude).

Pengembangan aktivitas belajar meliputi segi kognitif, afektif dan psikomotorik (Setiawan, 2000) sebagai berikut:

a. Pengembangan kognitif, antara lain dilakukan dengn merangsang kelancaran, kelenturan dan keaslian dalaam berpikir.

b. Pengembangan efektif, dilakukan dengn memupuk sikap dan minat untuk bersibuk diri secara kreativ.

c. Pengembangan psikomotorik, dilakukan dengn menyediakan sarana dan prasarana yaang memungkinkan siswa mengembangkan keterampilannya dalaam membuat karya-karya produktif.

\section{Prestasi Belajar}

Prestasi adalah hasil yaang telah dicapai, dilakukan dan dikerjakan berupa kesan-kesan hasil darii yaang mengakibatkan perubahan dalaam diri individu sebagai hasil darii aktfitas dalaam belajar (Djamarah 1994 : 23).

Setiap kegiatan atau usaha yaang telah dilakukan perlu diadakan penilaian untuk mengetehui sejauh mana tingkat keberhasilan yaang dicapai sehingga dapat diketahui apakah tujuan kegiatan tersebut telah tercapai atau belum. Tingkat keberhasilan yaang telah dicapai disebut dengn istilah prestasi

Belajar adalah suatu kegiatan yaang bernilai edukatif. Nilai edukatif mewarnai interaksi antara guru dengn anak didik. Kegiatan belajar merupakan suatu proses yaang rumit karena tidak sekedar menyerap informasi darii guru tetapi melibatkan berbagai kegiatan trutama bila di inginkan hasil yaang baik. Setiap kegiatan belajar akan menghasilkan perubahan padaa siswa yaang tampak padaa tingkah laku atau prestasi siswa (Djamarah :1994:23). Adapun prestasi belajar adalah hasil yaang diperoleh berupa kesan-kesan yaang mengakibatkan perubahan dalaam individu sebagai hasil darii aktifitas dalaam belajar (Djamarah : 1994:23).

Pengertian prestasi belajar yaang dinyatakan di atas, tidak terlepas darii hasil aktivitas belajar, sehingga dapat disimpulkan bahwa prestasi belajar adalah hasil darii kegiatan belajar, sedangkan hasil kegiatan belajar adalah penilaian kemampuan (penguasaan materi), penilaian keterampilan dan penilaian tingkah laku.

Prestasi belajar merupakan hasil interaksi berbagai faktor, baik faktor internal maupun faktor ekternal. Faktor-faktor tersebut baik secara terpisah maupun bersamasama memberikan kontribusi tertentu terhadap prestasi belajar peserta didik. Faktorfaktor tersebut meliputi:

a. Faktor Lingkungan, yaang mencakup:Lingkungan alami, Lingkungan sosial budaya.

b. Faktor Instrumental, yaang meliputi: Kurikulum, Program, Sarana dan prasarana, Guru. 
c. Kondisi Fsikologi meliputi; Minat, Kecerdasan, Bakat, Motivasi, Kemampun Kognitif (Djamarah, 2003:170).

\section{Metode Index card Match dalaam pembelajarn}

Berdasarkan Peraturan Pemerintah No.19/2005 pasal 19, dinyatakan bahwa proses pembelajarn padaa satuan pendidikan diselenggarakan secara interaktif, menyenangkan, menantang, memotivasi peserta didik untuk berpartisipasi aktif serta memberikan ruang yaang cukup bagi prakarsa, kreativitas dan kemandirian sesuai bakat, minat, dan perkembangan fisik seta fsikologis peserta didik.

Sehubungan dengn hal tersebut maka pengajar perlu menguasai dan dapat menerapkan berbagai strategi pembelajarn yaang meliputi pendekatan, metode dan teknik pembelajarn secara spesifik, karena penguasaan model pembelajarn akan mempengaruhi keberhasilan peserta didik dalaam pembelajarn. Model pembelajarn merupakan salah satu pendekatan dalaam rangka mensiasati perubahan perilaku peserta didik secara adaptif maupun generatif. Model pembelajarn sangat erat kaitannya dengn gaya belajar peserta didik (learning style) dan gaya mengajar guru (teaching style), yaang keduanya disingkat menjadi SOLAT (Style of Learning and Teaching).

Adapun model-model pembelajarn peserta didik yaang dapat diterapkan dalaam pembelajarn seperti: Examples Non-Examples, Ficture and Ficture, Numbered Head Together, Cooperative Script, Jigsaw, STAD, Index Card Match dan sebagainya.

Metode Index Card Match merupakan metode belajar mengajar yaang dilakukan dengn cara memanfaatkan kartu yaang telah diberikan tanda berdasarkan aturan kesamaan atau kesesuain. Menurut bahasa Index Card Match artinya mencari pasangan, atau lebih jelasnya mencari pasangan kartu. Index Card Match merupakan sebuah strategi pembelajarn yaang membantu siswa untuk mendapat pengetahuan, keterampilan, dan sikap secara aktif serta menjadikan belajar tidak terlupakan (Suprijono, A., 2005:120). Mengingat bahwa materi pelajaran langsung menjadi bagian darii aktivitas belajar siswa. Jadi setiap bagian yaang menjadi inti materi pelajaran telah tertuang dalaam kertas-kertas yaang akan dicocokkan oleh siswa.

Secara sederhana Card Match merupakan gabungan kata yaang berarti mencocokkan kartu, sehingga dapat dipahami bahwa ada dua buah kartu atau lebih yaang harus dicocok oleh siswa dalaam belajar. Kartu-kartu tersebut telah diisi dengn materi pelajaran yaang sedang dipelajari oleh siswa. Dalaam hal ini indexs yaang dimaksud adalah materi pelajaran tersebut. Oleh karena itu kegiatan Index Card Match adalah kegiatan mencocokkan materi pelajaran yaang telah tertuang dalaam pasangan kertas. Dalaam proses pelaksanaannya kertas atau kartu yaang telah terisi materi pelajaran tersebut tinggal dicari dan dihubungkan maknanya oleh siswa.

Dalaam pelaksanaannya. Peneraan metode Index Card Match dapat digolongkan menjadi dua, yaitu:

a. Individu

Penerapan secara individual dapat dilaksanakan dengn cara siswa masingmasing siswa dibagikan 1 kertas. Kemudian guru menyiapkan pasangan kertas tersebut padaa satu tempat. Kemudian masing siswa-siswa berusaha untuk mencari pasangan kertas yaang dipegang padaa media yaang telah disiapkan oleh guru. 
Kelemahan darii pola ini adalah siswa berkonsentrasi padaa satu tempat dan kemungkinan kelas tidak terkendali darii keributan. Sehingga, jika mungkin untuk menerapkan pola ini maka guru harus benar-benar menata sistem kelas yaang bagus sehingga kelas tidak terlalu ribut.

b. Berkelmpok

Penerapan secara berkelmpok dapat dilakukan dengn cara membagi kelas menjadi beberapa kelmpok siswa. Masing-masing kelmpok dibekali dengn kartu atau kertas materi pelajaran sesuai dengn jumlah kelmpoknya. Masing-masing anggota kelmpok memegang dua buah kertas yaang masih bersifat acak.

Kegiatan pencocokan dilaksanakan dengn cara masing-masing anggota kelmpok mencari teman yaang menjadi pasangan kartunya. Dengn demikian, maka jika pasangan kertas telah ditemukan selanjutnya pasangan tersebut memberikan tafsiran dan dituangkan dalaam bentuk tulisan tentang isi materi yaang telah didapatkan.

Metode Index Card Match, memberikan peran yaang lebih banyak kepadaa siswa dalaam kegiatan belajar, karena masing-masing siswa tentunya dilengkapi dengn kartu atau paling tidak setiap siswa akan terkonsentrasi dimasing-masing kelmpok belajar untuk melakukan kegiatan pencocokan kartu materi pelajaran.

\section{METODE PENELITIAN}

\section{Rancangan Penelitian}

Rancangan penelitian dapat diartikan sebagai mengatur latar (setting) penelitian agar peneliti memperoleh data yaang tepat (valid) sesuai dengn karakteristik variabel dengn tujuan penelitian.

Penelitian ini dilaksanakan dalaam beberapa siklus, prosedur ini dilaksanakan dengn harapan dapat memberikan gambaran analisis data akurat sesuai dengn perubahan yaang ingin dicapai. Perolehan data darii setiap siklus dijadikan sebagai dasar untuk melakukan tindakan padaa siklus berikutnya, pelaksanaan tindakan darii masing-masing siklus terdiri darii perencanaan, pelaksanaan tindakan, pengamatan/observasi dan refleksi.

Dalaam setiap siklus terdiri darii 4 (empat) tahap yaitu perencanaan, pelaksanaan tindakan, observasi, dan refleksi. Secara rinci perencanaan tindakan untuk setiap siklus dapat dijabarkan sebagai berikut:

a. Perencanaan

Kegiatan yaang dilakukan padaa tahap perencanaan ini adalah membuat RPP, skenario pembelajarn, lembar observasi aktivitas guru, lembar observasi aktivitas siswa, membuat kartu materi pelajaran, mendesain alat evaluasi atau membuat LKS dan merencanakan analisis hasil tes.

b. Pelaksanaan Tindakan

Kegiatan yaang dilaksanakan dalaam tahap ini adalah melaksanakan semua hal yaang telah direncanakan padaa tahap perencanaan dan melaksanakan skenario pembelajarn di kelas.

c. Observasi dan Evaluasi

Kegiatan observasi dilaksanakan padaa saat proses belajar mengajar berlangsung untuk melihat bagaimana proses belajar mengajar apakah telah sesuai dengn skenario yaang telah dibuat. 
Perilaku aktivitas guru sesuai dengn rencana pelaksanaan pembelajarn dan aktivitas belajar siswa dicatat dalaam lembar observasi yaang telah disediakan. Sedangkan evaluasinya dilakukan dengn memberikan tes padaa akhir tindakan atau akhir setiap siklus untuk mengetahui sejauh mana penguasaan materi yaang telah diberikan.

d. Refleksi

Kegiatan dilaksanakan padaa tahap ini adalah mencermati, mengkaji, dan menganalisis secara mendalaam dan menyeluruh tindakan yaang telah dilaksanakan yaang didasarkan data yaang terkumpul padaa langkah observasi. Analisis data atau hasil tes ditujukan untuk memperbaiki hasil materi pembelajarn, sedangkan analisis lembar observasi digunakan untuk memperbaiki tindakan penelitian di dalaam kelas. Hasil analisa data yaang dilakukan padaa tahap ini akan digunakan sebagai acuan untuk merencanakan siklus berikutnya.

Setelah siklus I selesai dilaksanakan maka hasil analisanya dipergunakan langsung sebagai acuan penyusunan perencanaan padaa siklus II.

Kegiatan yaang dilaksanakan padaa siklus dua sama dengn kegiatan yaang dilaksanakan padaa siklus pertama. Apa yaang menjadi kekurangan padaa siklus pertama disempurnakan padaa siklus kedua. Kegiatan padaa siklus II tetap melalui tahap perencanaan, tindakan, observasi dan refleksi. Adapun hasil darii siklus II selanjutnya menjadi acuan untuk memperbaiki serta menyempurnakan perencanaan dan pelaksanaan tindakan padaa siklus III, dan seterusnya.

\section{Instrumen Penelitian}

Instrumen adalah alat atau teknik yaang digunakan untuk memperoleh data (Sudjana, 2002: 14). Instrumen juga diartikan sebagai alat padaa waktu peneliti menggunakan suatu metode (Suharsimi, 2002: 137). Adapun instrumen yaang digunakan adalah:

\section{Skenario Pelaksanaan Pembelajarn}

Skenario disebut juga dengn rencana. Rencana pelaksanaan pembelajarn biasanya lebih efektif dan efisien dalaam menyampaikan materi yaang akan disampaikan di dalaam kelas dimana rencana ini berisi gambaran global darii materi yaang akan disampaikan.

\section{Rencana Pelaksanaan Pembelajarn (RPP)}

RPP merupakan pedoman pelaksanaan pembelajarn yaang disusun oleh guru untuk tiap tatap muka kegiatan belajar;

\section{Pedoman Observasi Guru}

Pedoman Observasi Kinerja Guru merupakan alat untuk menilai aktivitas guru dalaam mengajar. Pedoman ini berisi tentang indikator keterlaksanaan program pembelajarn.

\section{Pedoman Observasi Siswa}

Pedoman Observasi Kinerja Siswa merupakan alat untuk menilai aktivitas masing-masing siswa dalaam kegiatan belajar. Pedoman ini berisi tentang indikator keaktifan siswa.

\section{Tes}

Tes adalah serentetan pertanyaan atau latihan atau alat lain yaang digunakan untuk mengukur keterampilan, pengetahuan, intelegensi, kemampuan atau bakat 
yaang dimiliki oleh individu atau kelmpok (Suharsimi, 2002: 139). Tes diberikan untuk memperoleh data tentang prestasi akademik siswa padaa setiap akhir siklus. Tes yaang diberikan kepadaa siswa seluruhnya diambil darii buku paket Matematika.

\section{Teknik Pengumpulan Data}

Adapun metode pengumpulan data yaang dipergunakan dalaam penelitian ini adalah sebagai berikut:

1. Sumber Data

Sumber data penelitian ini adalah:

a. Siswa

b. Peneliti sebagai pengajar

c. Guru sebagai observer.

2. Jenis Data

Jenis data yaang diperoleh darii penelitian ini adalah:

a. Data kualitatif berupa hasil observasi aktivitas siswa dan proses mengajar yaang dilaksanakan oleh guru.

b. Data kuantitatif berupa data hasil evaluasi belajar siswa.

3. Teknik Pengambilan Data

Teknik pengambilan data padaa penelitian ini adalah:

a. Data observasi guru diperoleh darii pedoman observasi guru.

b. Data observasi siswa diperoleh darii pedoman observasi siswa.

c. Data tentang hasil belajar siswa diperoleh dengn cara memberikan tes evaluasi siswa setiap akhir siklus.

\section{Teknik Analisis Data}

1. Data Prestasi Belajar Siswa

Setelah memperoleh data tes hasil belajar, maka data tersebut dianalisis dengn mencari ketuntasan belajar, yaang kemudian dianalisis secara kuantitatif :

2. Ketuntasan Individu

Setiap siswa dalaam proses belajar mengajar dikatakan tuntas apabila memperoleh nilai lebih besar atau sama dengn 60. Nilai ketuntasan minimal sebesar 60 dipilih karena disesuaikan dengn KKM (Kriteria Ketuntasan Minimal) sekolah tersebut.

3. Ketuntasan Klasikal

Data tes hasil proses belajar dan pembelajarn dianalisis dengn menggunakan analisis ketuntasan minimal $85 \%$ darii jumlah siswa yaang memperoleh nilai $\geq 60$. Sesuai dengn petunjuk teknis penilaian suatu kelas dikatakan tuntas secara klasikal terhadap materi yaang disajikan jika ketuntasan klasikal mencapai $\geq 85 \%$.

4. Nilai Rata-rata kelas

Untuk mengetahui nilai rata-rata kelas digunakan rumus sebagai berikut (Nasution, 1996):

$$
\mathrm{R}=\frac{\sum X}{N}
$$

Dimana :

$\mathrm{R}=$ Nilai rata - rata kelas

$\Sigma \mathrm{x}=$ Jumlah nilai yaang diperoleh siswa 
5. Data Aktivitas Siswa

$$
\mathrm{N}=\text { Jumlah seluruh siswa yaang mengikuti tes }
$$

Data tentang aktivitas belajar siswa dianalisis secara deskriptif kualitatif. Indikator tentang aktivitas belajar siswa yaang diamati adalah sebanyak 7 indikator. Setiap indikator memiliki 3 deskriptor. Adapun skor untuk setiap deskriptor aktivitas siswa padaa penelitian ini mengikuti aturan sebagai berikut :

a. Skor 4 diberikan jika semua deskriptor nampak

b. Skor 3 jika 2 deskriptor nampak

c. Skor 2 jika 1 deskriptor nampak

d. Skor 1 jika tidak ada deskriptor

Pemberian skor 1 jika tidak ada deskriptor yaang nampak disebabkan karena adanya kehadiran siswa di dalaam kelas, sehingga secara tidak langsung siswa tersebut memperoleh pengetahuan yaang disampaikan oleh guru.

Berdasarkan aturan tersebut, maka skor rata-rata minimal dan maksimal aktivitas belajar siswa masing-masing adalah 7 dan 28, sehingga interval rata-rata skor aktivitas belajar siswa berada antara 7 dan 28 .

Berdasarkan skor standar, maka kriteria untuk menentukan aktivitas belajar siswa dijabarkan padaa tabel berikut ini:

Tabel 2. Pedoman Kriteria Aktivitas Belajar Siswa (Individual)

\begin{tabular}{|c|c|c|}
\hline Interval & Nilai & Kriteria \\
\hline $\mathrm{Mi}+1,5 \mathrm{SDi} \leq \mathrm{As}$ & $\mathrm{As} \geq 26,25$ & Sangat aktif \\
\hline $\mathrm{Mi}+0,5 \mathrm{SDi} \leq \mathrm{As}<\mathrm{Mi}+1,5 \mathrm{Sdi}$ & $20,42 \leq \mathrm{As}<26,25$ & Aktif \\
\hline $\mathrm{Mi}-0,5 \mathrm{SDi} \leq \mathrm{As}<\mathrm{Mi}+0,5 \mathrm{Sdi}$ & $14,58 \leq \mathrm{As}<20,42$ & Cukup aktif \\
\hline $\mathrm{Mi}-1,5 \mathrm{SDi} \leq \mathrm{As}<\mathrm{Mi}-0,5 \mathrm{Sdi}$ & $8,75 \leq \mathrm{As}<14.58$ & Kurang aktif \\
\hline $\mathrm{As}<\mathrm{Mi}-1,5 \mathrm{SDi}$ & $\mathrm{As}<8,75$ & Tidak aktif \\
\hline
\end{tabular}

Untuk data aktivitas siswa dikatakan berhasil apabila rata-rata skor aktivitas belajar siswa minimal berkategori aktif.

Tabel 3. Pedoman Kriteria Aktivitas Belajar Siswa (Klasikal)

\begin{tabular}{|c|c|c|}
\hline Interval & Nilai & Kriteria \\
\hline $\mathrm{Mi}+1,5 \mathrm{SDi} \leq \mathrm{As}$ & $\mathrm{As} \geq 630$ & Sangat aktif \\
\hline $\mathrm{Mi}+0,5 \mathrm{SDi} \leq \mathrm{As}<\mathrm{Mi}+1,5 \mathrm{Sdi}$ & $490 \leq \mathrm{As}<630$ & Aktif \\
\hline $\mathrm{Mi}-0,5 \mathrm{SDi} \leq \mathrm{As}<\mathrm{Mi}+0,5 \mathrm{Sdi}$ & $350 \leq \mathrm{As}<490$ & Cukup aktif \\
\hline $\mathrm{Mi}-1,5 \mathrm{SDi} \leq \mathrm{As}<\mathrm{Mi}-0,5 \mathrm{Sdi}$ & $210 \leq \mathrm{As}<350$ & Kurang aktif \\
\hline $\mathrm{As}<\mathrm{Mi}-1,5 \mathrm{SDi}$ & $\mathrm{As}<210$ & Tidak aktif \\
\hline
\end{tabular}

6. Data Hasil Observasi Guru

Penilaian aktivitas guru dianalisis secara deskriptif kualitatif. Indikator tentang aktivitas guru yaang diamati adalah sebanyak 9 indikator. Setiap indikator memiliki 3 deskriptor. Adapun skor untuk setiap deskriptor aktivitas guru padaa penelitian ini mengikuti aturan sebagai berikut :

a Skor 4 diberikan jika semua deskriptor nampak 
b Skor 3 jika 2 deskriptor nampak

c Skor 2 jika 1 deskriptor nampak

d Skor 1 jika tidak ada deskriptor

Pemberian skor 1 jika tidak ada deskriptor yaang nampak disebabkan karena adanya usaha yaang dilakukan guru untuk melaksanakan deskriptor tersebut, namun tidak nampak secara langsung.

Berdasarkan aturan tersebut, maka skor minimal dan maksimal aktivitas guru masing-masing adalah 9 dan 36, sehingga interval skor aktivitas guru berada antara 9 dan 36. Berdasarkan skor standar, maka kriteria untuk menentukan aktivitas belajar guru dijabarkan padaa tabel berikut ini:

Tabel 4. Pedoman Kriteria Aktivitas Mengajar Guru

\begin{tabular}{|c|c|c|}
\hline Interval & Nilai & Kriteria \\
\hline $\mathrm{Mi}+1,5 \mathrm{SDi} \leq \mathrm{Ag}$ & $\mathrm{Ag} \geq 33,75$ & Sangat Baik \\
\hline $\mathrm{Mi}+0,5 \mathrm{SDi} \leq \mathrm{Ag}<\mathrm{Mi}+1,5 \mathrm{SDi}$ & $26,25 \leq \mathrm{Ag}<33,75$ & Baik \\
\hline $\mathrm{Mi}-0,5 \mathrm{SDi} \leq \mathrm{Ag}<\mathrm{Mi}+0,5 \mathrm{SDi}$ & $18,75 \leq \mathrm{Ag}<26,25$ & Cukup Baik \\
\hline $\mathrm{Mi}-1,5 \mathrm{SDi} \leq \mathrm{Ag}<\mathrm{Mi}-0,5 \mathrm{SDi}$ & $11,25 \leq \mathrm{Ag}<18,75$ & Kurang Baik \\
\hline $\mathrm{Ag}<\mathrm{Mi}-1,5 \mathrm{SDi}$ & $\mathrm{Ag}<11,25$ & Sangat Kurang \\
\hline
\end{tabular}

Untuk data aktivitas guru dikatakan berhasil apabila skor aktivitas guru minimal berkategori baik.

\section{HASIL DAN PEMBAHASAN}

\section{Data Hasil Pelaksanaan Penelitian Siklus I}

\section{Hasil Observasi Aktivitas Mengajar Guru}

Semua deskriptor yaang ada padaa lembar observasi aktivitas mengajar guru sudah dilakukan oleh guru dimana padaa pertemuan I aktivitas guru berkategori cukup baik dan pertemuan II dikategorikan baik, sehingga indikator aktivitas mengajar guru padaa siklus I dapat disimpulkan dengn berkategori baik.

Data aktivitas mengajar guru dapat dilihat padaa gambar 1 grafik aktivitas mengajar guru siklus I.

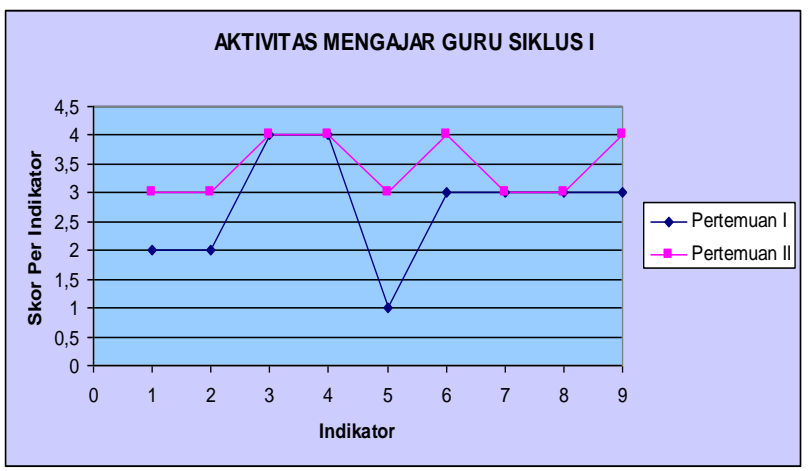

Gambar 1. Grafik Aktivitas Mengajar Guru Siklus I

Darii gambar 1 dapat dilihat bahwa aktivitas mengajar guru padaa pertemuan I terdapat banyak kekurangan. Terutama padaa indikator ke-5, tidak ada deskriptor yaang nampak sehingga skor yaang diberikan adalah 1 . Indikator ini belum tercapai 
sama sekali, ini disebabkan karena guru tidak mengatur waktu mengerjakan LKS dan mempertegas batasan waktu kerja kelmpok kepadaa siswa, yaang mengakibatkan sebagian besar siswa tidak serius padaa waktu kerja kelmpok sehingga waktu kerja kerjasama antar anggota kelmpok kurang optimal.

\section{Hasil Observasi Aktivitas Belajar Siswa}

Observasi terhadap aktivitas belajar siswa dilakukan dengn mengamati prilaku siswa padaa saat proses pembelajarn berlangsung. Semua aktivitas yaang nampak dicatat dalaam lembar observasi aktivitas belajar siswa dan pemberian skor sesuai dengn deskriptor yaang nampak.

Data hasil observasi aktivitas belajar siswa siklus I juga dapat dilihat padaa gambar 2 grafik aktivitas belajar siswa siklus I di bawah ini :

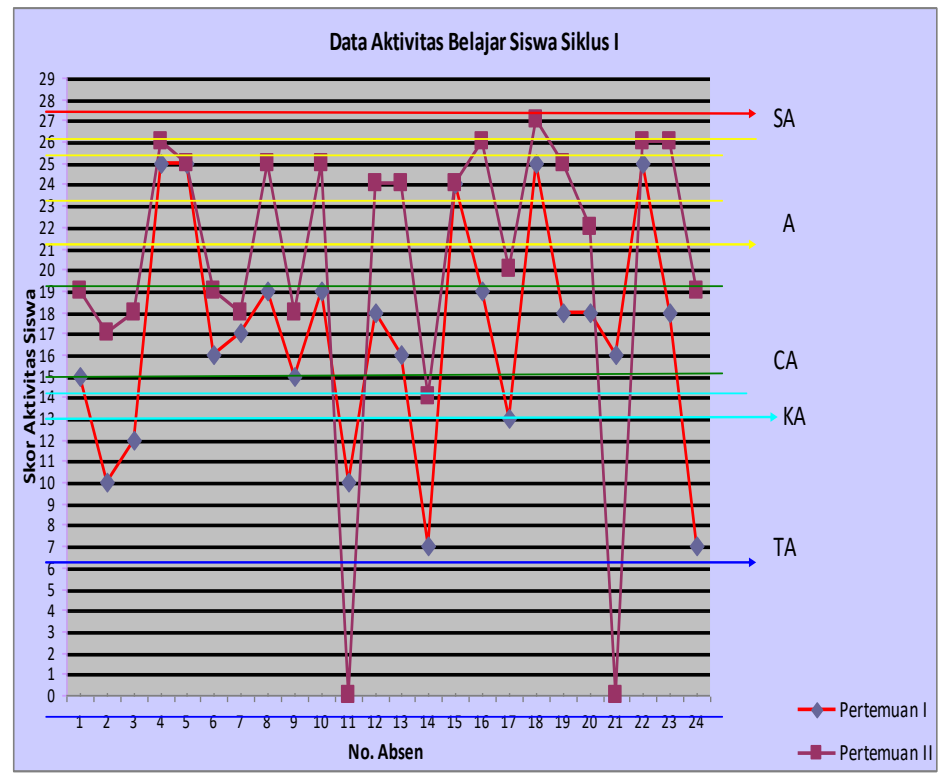

Gambar 2. Grafik Aktivitas Belajar Siswa Siklus I

Darii grafik 2. di atas dilihat aktivitas belajar siswa siklus I dikategorikan cukup aktif. Hal ini berdasarkan pedoman konversi aktivitas belajar siswa, data aktivitas belajar siswa darii siklus I pertemuan pertama, 5 siswa padaa kategori aktif, 13 siswa padaa kategori cukup aktif, 4 siswa padaa kategori kurang aktif, karena dan 2 siswa padaa kategori sangat tidak aktif. Data ini meningkat padaa pertemuan kedua menjadi 1 siswa kategori sangat aktif, 12 siswa kategori aktif, 8 siswa padaa kategori cukup aktif, 1 siswa padaa kategori kurang aktif dan 2 siswa yaang tidak aktif yaang disebabkan karena siswa tersebut tidak hadir.

\section{Hasil Evaluasi Belajar}

Setelah melakukan kegiatan pembelajarn sebanyak dua kali pertemuan, maka padaa pertemuan ketiga guru memberikan evaluasi kepadaa siswa. Evaluasi berlangsung selama 1 jam pelajaran. Bentuk soal evaluasi adalah essay sebanyak 7 butir soal untuk dikerjakan secara individu. Masing-masing siswa mendapatkan satu lembar soal. Jawaban siswa kemudian diperiksa dengn skor maksimal 100 jika semua jawaban siswa benar dan skor minimal 0 jika siswa tidak menjawab sama sekali 
Setelah diadakan evaluasi kepadaa siswa padaa materi pokok persegi dan persegi panjang, diperoleh data hasil belajar siswa padaa siklus I menunjukkan bahwa nilai rata-rata kelas adalah 61,08 dan siswa yaang memenuhi kriteria ketuntasan belajar individu bejumlah 18 orang siswa dan 6 orang siswa yaang belum tuntas darii 24 siswa yaang ikut tes. Nilai ini belum memenuhi indikator kerja yaang telah ditentukan sebelumnya.

Darii 7 soal evaluasi yaang diberikan, soal nomor 4 dan 5 yaang paling rendah nilainya artinya masih banyak siswa yaang masih mengalami keliru menempatkan jawaban darii soal yaang diberikan yaitu tentang definisi persegi dan persegi panjang dan contoh-contoh benda yaang menyerupai persegi dan persegi panjang. Maka perlu dilakukan perbaikan padaa pertemuan siklus berikutnya, yaitu padaa pertemuan siklus berikutnya akan diberikan bimbingan dan perhatian khusus di kelas ketika proses belajar mengajar berlangsung di samping itu juga guru memberikan upaya dalaam mengendalikan kendala yaang dihadapi atau penyebab lain yaang dialami oleh 6 orang siswa tersebut. Karena penelitian padaa siklus I belum mencapai ketuntasan belajar klasikal, maka peneliti merencanakan tindakan perbaikan padaa siklus II.

Melalui analisis evaluasi belajar nilai rata-rata siswa dan ketuntasan belajar siswa dapat dilihat padaa tabel berikut:

Tabel 5. Data Hasil Evaluasi Belajar Siswa Siklus I MTs. Darul Kamilin Jati Bakan Tahun Pelajaran 2019/2020

\begin{tabular}{|c|c|c|c|c|}
\hline $\begin{array}{c}\text { Banyak } \\
\text { Siswa }\end{array}$ & $\begin{array}{c}\text { Skor } \\
\text { Total }\end{array}$ & $\begin{array}{c}\text { Nilai } \\
\text { Rata-Rata }\end{array}$ & $\begin{array}{c}\text { Banyak Siswa } \\
\text { Yaang Tuntas }\end{array}$ & $\begin{array}{c}\text { Persentase } \\
\text { Ketuntasan }\end{array}$ \\
\hline 24 & 1466 & 61,08 & 18 & $75 \%$ \\
\hline
\end{tabular}

Data hasil evaluasi belajar siswa siklus I dapat dilihat padaa gambar 3.grafik hasil evaluasi belajar siswa siklus I

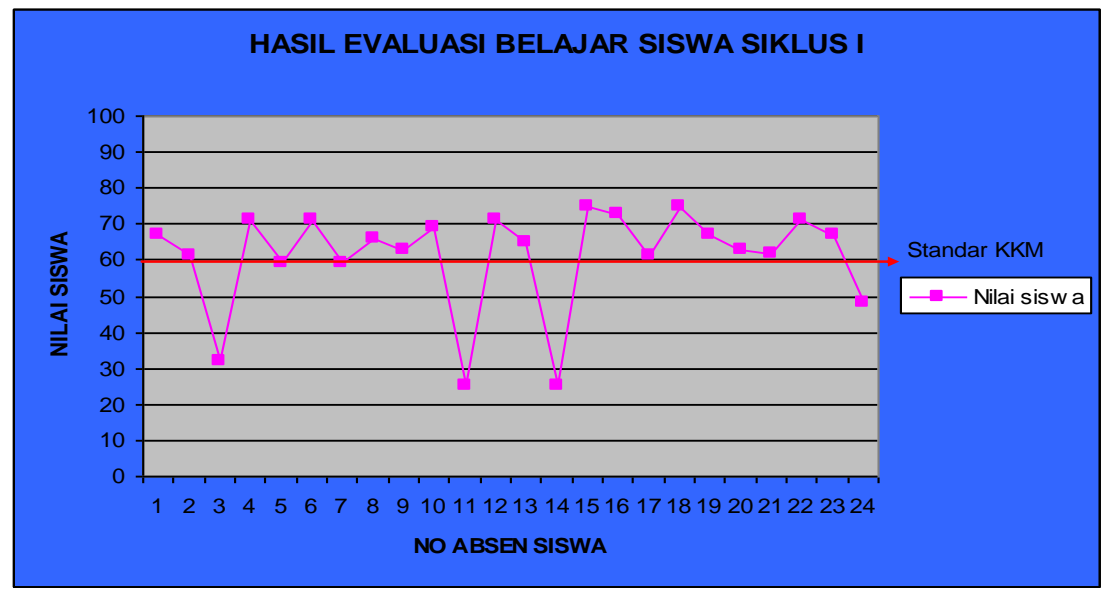

Gambar 3 grafik hasil evaluasi belajar siswa siklus I

Berdasarkan grafik padaa gambar 4.3 dapat dilihat bahwa terdapat 6 orang siswa yaang dikategorikan tidak tuntas karena nilainya dibawah standar KKM yaitu 60. siswa yaang tidak tuntas ini mengalami kesulitan padaa beberapa item soal. Adapun kesulitan yaang dialami siswa serta langkah- langkah perbaikannya sebagai berikut: 


\section{Refleksi}

Dilihat darii aktivitas belajar siswa padaa siklus 1 belum memenuhi indikator keberhasilan peneliltian secara keseluruhan maka penelitian dilanjutkan ke siklus II Pelaksanaan siklus II dengn memperbaiki kekurangan - kekurangan yaang muncul padaa siklus 1 diantaranya.:

Tabel 6. Hambatan/kekurangan siswa dan langkah-langkah perbaikan yaang muncul padaa siklus I.

\begin{tabular}{|c|c|c|}
\hline No & Hambatan / Kekurangan & Langkah Perbaikan \\
\hline 1 & $\begin{array}{l}\text { Siswa masih ragu-ragu dalaam } \\
\text { merespon pelajaran }\end{array}$ & $\begin{array}{l}\text { Guru harus mampu mengarahkan dan } \\
\text { membimbing siswa serta memberikan } \\
\text { rangsangan agar bisa merespon pelajaran } \\
\text { selama proses belajar mengajar } \\
\text { berlangsung }\end{array}$ \\
\hline 2 & $\begin{array}{l}\text { Siswa tidak berani bertanya } \\
\text { tentang materi yaang belum } \\
\text { mereka mengerti }\end{array}$ & $\begin{array}{l}\text { Guru harus memberikan penguatan dan } \\
\text { memberikan kebebasan bertanya kepadaa } \\
\text { siswa. }\end{array}$ \\
\hline 3 & $\begin{array}{l}\text { Kurangnya kerjasama antar } \\
\text { kelmpok untuk mengerjakan } \\
\text { tugas sampai tuntas }\end{array}$ & $\begin{array}{l}\text { Guru harus mengarahkan dan } \\
\text { membimbing siswa untuk bekerjasama } \\
\text { dengn kelmpoknya agar tugasnya bisa } \\
\text { diselesaikan sampai tuntas }\end{array}$ \\
\hline 4 & \begin{tabular}{llr} 
Siswa kurang & \multicolumn{2}{r}{ berinteraksi } \\
dengn siswa & lain & yaang \\
mengerjakan & soal & dan \\
memperbaiki & \multicolumn{2}{c}{ kesalahan } \\
temannya . & \multicolumn{2}{r}{}
\end{tabular} & $\begin{array}{l}\text { Guru harus mengarahkan dan } \\
\text { membimbing siswa untuk memperbaiki } \\
\text { kesalahan temannya dalaam mengerjakan } \\
\text { soal }\end{array}$ \\
\hline 5 & $\begin{array}{l}\text { Kurangnya perhatian siswa } \\
\text { untuk menanggapi pendapat } \\
\text { darii kelmpok sendiri }\end{array}$ & $\begin{array}{l}\text { Guru harus mampu mengarahkan dan } \\
\text { membimbing siswa untuk memberikan } \\
\text { tanggapan padaa kelmpok sendiri }\end{array}$ \\
\hline 6 & $\begin{array}{l}\text { Suasana belajar tidak selalu } \\
\text { kondusif }\end{array}$ & $\begin{array}{l}\text { Guru harus aktif mengatur jalannya } \\
\text { diskusi }\end{array}$ \\
\hline No & Hambatan / Kekurangan & Langkah Perbaikan \\
\hline 7 & $\begin{array}{l}\text { Siswa belum } r \text { mampu } \\
\text { mengambil dan membuat } \\
\text { kesimpualan darii materi yaang } \\
\text { dibahas }\end{array}$ & $\begin{array}{l}\text { Guru harus mengarahkan siswa untuk } \\
\text { mencari dan menemukan kesimpulan darii } \\
\text { materi yaang dibahas. }\end{array}$ \\
\hline
\end{tabular}

\section{Data Hasil Pelaksanaan Penelitian Siklus II}

\section{Hasil Observasi Aktivitas Mengajar Guru}

Seperti halnya padaa siklus I, siklus II juga di lakukan observasi padaa saat guru melakukan kegiatan pembelajarn. Darii hasil observasi padaa saat guru melakukan kegiatan, semua deskriptor yaang ada padaa lembar observasi sudah dilakukan oleh guru sehingga berkategori sangat baik. Hal ini berarti telah memenuhi indikator keberhasilan penelitian. 
Data aktivitas guru juga dapat dilihat padaa gambar 4.4 grafik aktivitas mengajar guru siklus II di bawah, dimana padaa pertemuan pertama siklus II terjadi peningkatan yaitu rata-rata deskriptor sudah nampak. Sedangkan pertemuan kedua siklus II deskriptor sudah nampak semua sehingga aktivitas mengajar guru berkategori sangat baik.

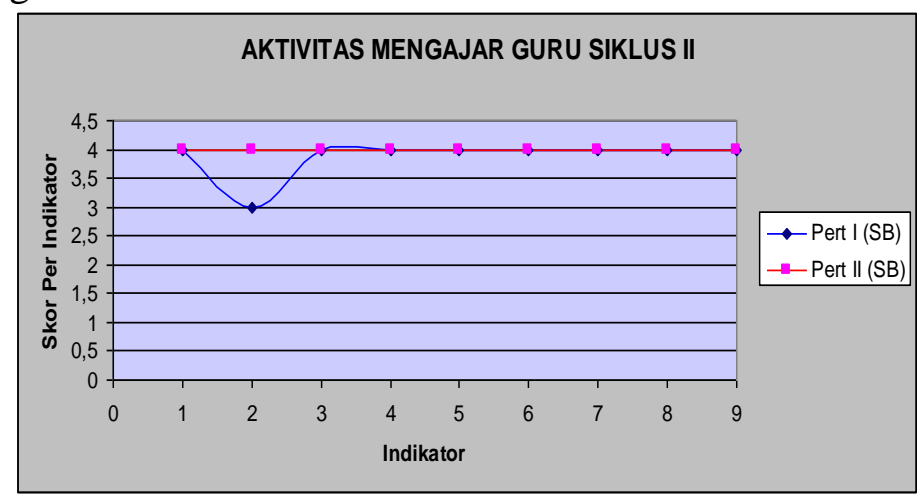

Gambar 4. Grafik Aktivitas Mengajar Guru Siklus dan II

Padaa Siklus II, proses belajar mengajar berlangsung dengn baik seperti: (a). Siswa telah serius mengerjakan tugas padaa waktu kerja kelmpok, (b). Siswa sudah mampu merespon pelajaran dengn baik dan sudah bisa beradaptasi dengn gurunya, (c). Siswa sudah mampu menerima pelajaran yaang diberikan dengn baik, (d). Siswa sudah betah dengn anggota kelmpoknya, (e). Siswa sudah mulai serius padaa waktu kerja kelmpok sehingga waktunyatidak terbuang sia-sia, (f). Siswa sudah mencoba mengerjakan soal latihan yaang diberikan bukan hanya menyalin jawaban temannya saja, (g). Kegiatan guru yaang sudah terlaksana dengn baik diantaranya memberikan apersepsi, menyampaikan materi, pendampingan siswa dalaam diskusi kelmpok dan sudah bisa menyimpulkan materi pembelajarn tersebut.

\section{Hasil Observasi Aktivitas Siswa}

Data hasil observasi aktivitas belajar siswa siklus II dapat disimpulkan bahwa aktivitas belajar siswa dikategorikan aktif. Hasil datanya dapat dilihat padaa gambar 4.5 grafik aktivitas belajar siswa siklus II.

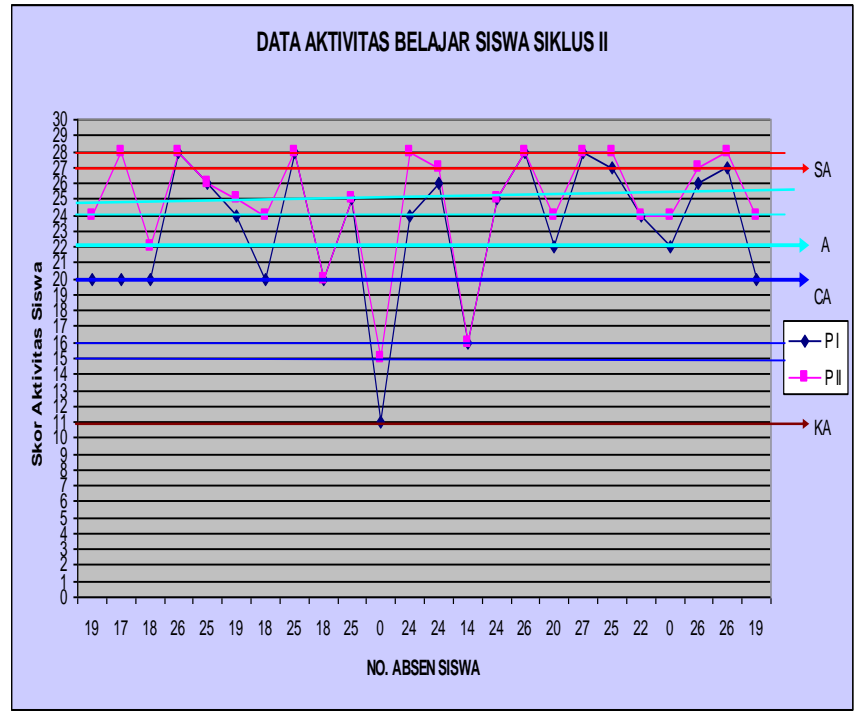

Gambar 5. Grafik Aktivitas Belajar Siswa Siklus II 
Padaa siklus II pertemuan I, masih ada 1 siswa yaang dikategorikan kurang aktif, ini disebabkan karena siswa tersebut masih tidak mau mencoba bertanya kepadaa teman yaang lebih mampu atau tidak berinteraksi dengn temannya dan tidak mencoba memperbaiki kesalahan sebelumnya serta tidak ikut berpartisipasi menyimpulkan hasil belajar. Padaa pertemuan I ini, tindakan perbaikan yaang dilakukan guru adalah melakukan pendekatan dan memberikan motivasi, serta arahan agar siswa tersebut lebih leluasa dan berani untuk bertanya, sehingga siswa tersebut bisa menyelesaikan soal yaang berkaitan dengn materi yaang dipelajari.

\section{Hasil Evaluasi Belajar}

Berdasarkan analisis hasil belajar siswa padaa siklus II menunjukkan bahwa nilai rata-rata kelas adalah 79,58 dan siswa yaang memenuhi ketuntasan belajar individu sebanyak 22 orang darii 24 orang siswa yaang ikut tes. Darii data tersebut dapat dikatakan bahwa prestasi belajar siswa telah mengalami peningkatan disiklus I ke siklus II yaitu sebesar 18,5

Melalui analisis evaluasi belajar nilai rata-rata siswa dan ketuntasan belajar siswa dapat dilihat padaa tabel berikut:

Tabel 7. Data Hasil Evaluasi Belajar Siswa Siklus II SMP Negeri 1 Wera tahun Pelajaran 2019/2020

\begin{tabular}{|c|c|c|c|c|}
\hline $\begin{array}{c}\text { Banyak } \\
\text { Siswa }\end{array}$ & $\begin{array}{c}\text { Skor } \\
\text { Total }\end{array}$ & $\begin{array}{c}\text { Nilai } \\
\text { Rata-Rata }\end{array}$ & $\begin{array}{c}\text { Banyak Siswa } \\
\text { Yaang Tuntas }\end{array}$ & $\begin{array}{c}\text { Persentase } \\
\text { Ketuntasan }\end{array}$ \\
\hline 24 & 1910 & 79,58 & 22 & $91,67 \%$ \\
\hline
\end{tabular}

Berdasarkan hasil analisa darii tabel 7 di atas terlihat bahwa ketuntasan belajar secara klasikal sudah mencapai darii target $85 \%$, ini berarti proses pembelajarn padaa siklus II sudah dikatakan berhasil atau tuntas. Hasil analisis secara rinci tentang data hasil evaluasi belajar siswa siklus II. Walaupun hasilnya telah tuntas tetapi untuk siswa yaang belum tuntas masih diberikan remedial sehingga siswa mencapai ketuntasan belajar ideal.

Data hasil evaluasi belajar siswa siklus II dapat dilihat padaa gambar 6 grafik hasil evaluasi belajar siswa siklus II dibawah ini:

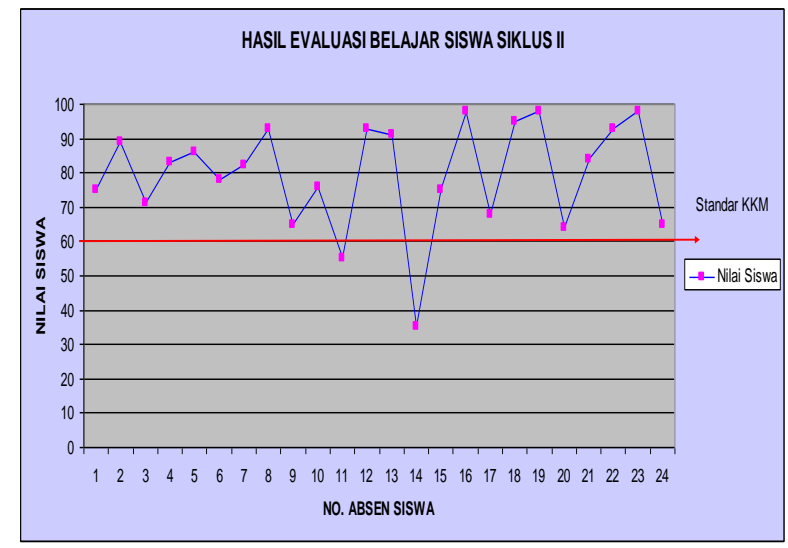

Gambar 6. Grafik Hasil Evaluasi Belajar Siswa Siklus II

Adapun grafik perbandingan hasil evaluasi belajar siswa siklus I dan II dapat dilihat padaa gambar 7. grafik hasil evaluasi belajar siklus I dan II dibawah ini : 


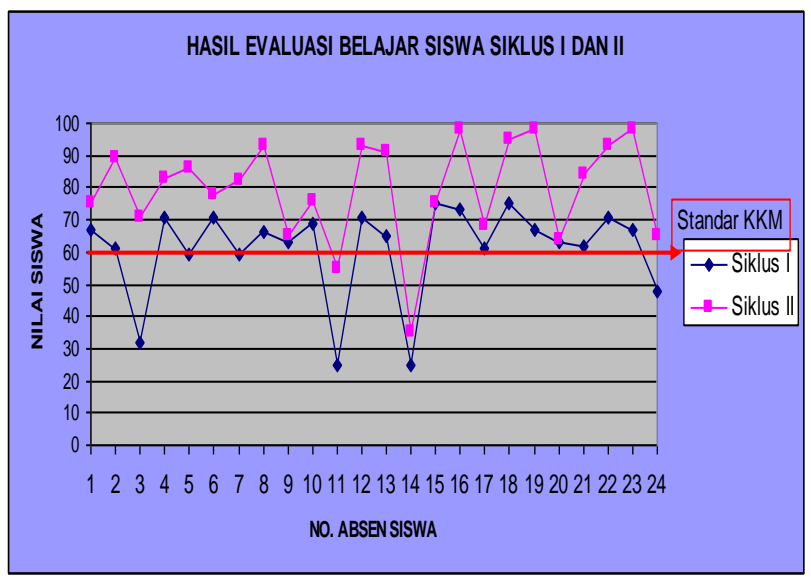

Gambar 7. Hasil Evaluasi Belajar Siswa Siklus I dan II

\section{Refleksi}

Berdasarkan hasil analisis evaluasi dan observasi aktivitas siswa padaa siklus II. Hasil yaang diperoleh sudah memenuhi indikator kinerja yaang telah ditentukan sebelumnya. Dimana sudah mencapai ketuntasan klasikal dan aktivitas siswa kategori aktif.

Adapun analisis kekurangan aktivitas belajar siswa padaa siklus II pertemuan pertama dan kedua seperti terlihat padaa tabel berikut ini:

Tabel 8. Data analisis kekurangan aktivitas belajar siswa siklus II

\begin{tabular}{|l|l|l|}
\hline No & \multicolumn{1}{|c|}{ Kekurangan } & \multicolumn{1}{c|}{ Langkah perbaikan } \\
\hline 1 & $\begin{array}{l}\text { Siswa masih kurang berani } \\
\text { mengacungkan tangannya untuk } \\
\text { maju mengerjakan soal }\end{array}$ & $\begin{array}{l}\text { Guru mencoba memberikan tambahan } \\
\text { nilai bagi siswa yaang mau maju } \\
\text { mengerjakan soal }\end{array}$ \\
\hline 2 & $\begin{array}{l}\text { Siswa kurang biasa mengomentari } \\
\text { dan memperbaiki kesimpulan } \\
\text { yaang di paparkan temannya }\end{array}$ & $\begin{array}{l}\text { Interaksi dan komunikasi dan analisis } \\
\text { darii suatu kasus harus diterapkan oleh } \\
\text { guru }\end{array}$ \\
\hline
\end{tabular}

\section{Pembahasan}

Padaa pertemuan pertama proses belajar mengajar tidak bejalan dengn efektif dan tidak sesuai denga RPP pembelajarn yaang dirancang. Banyak sekali waktu yaang terbuang oleh guru untuk memberikan penjelasan kepadaa siswa tentang Langkah-langkah metode pembelajarn yaitu metode Index Card Match yaang artinya mencari pasangan kartu. Walupun demikian siswa sudah mulai memahami tentang metode pembelajarn tersebut. Padaa pertemuan pertama guru memulai proses pembelajarn dengn materi pokok persegi dan persegi panjang yaang membahas tentang pengertian dan sifat-sifat serta contoh benda yaang menyerupai bangun persegi dan persegi panjang. Dengn bantuan kartu guru menyampaikan materi tersebut dengn bantuan kartu yaang berisikan ada kartu jawaban dan kartu soal.

Pertemuan kedua diajarkan menurunkan rumus menghitung luas dan keliling persegi dan persegi panjang, serta menyelesaikan soal-soal latihan dengn bantuan kartu yaitu mencari pasangan kartu soal atau kartu jawaban dengn aloksi waktu $2 \mathrm{x}$ 45 menit. Padaa pertemuan ini prose belajar mengajar sudah mulai berjalan dengn baik walupun masih ada beberapa kekuarangan komunikasi dan interaksi baik antar 
siswa dengn siswa maupun antar guru dengn siswa belum terlihat. Masih banyak siswa merasa malu untuk menyampaikan atau menanyakan kesulitan-kesulitan yaang mereka alami selama proses belajar mengajar. Ini perlu diperhatikan oleh guru supaya konsep yaang dibahas bisa dimengerti dan dipahami oleh semua siswa.

Jumlah siswa yaang mengikuti proses pembelajarn sebanyak 24 siswa berdasarkan grafik 4.2. menunjukan bahwa padaa siklus I pertemuan pertama jumlah siswa padaa kategori aktif sebanyak 5 siswa, 13 siswa padaa kategori cukup aktif dan 4 siswa padaa kategori kurang aktif dan 2 siswa yaang masih berkategori tidak aktif. Sedangkan pertemuan kedua siklus I mengalami peningkatan yaitu 1 siswa dikategorikan sangat aktif, 12 siswa kategori aktif, 8 siswa kategori cukup aktif, 1 siswa kategori kurang aktif dan 2 siswa dikategorikan tidak aktif karena siswa yaang bersangkutan tidak hadir. Adapun analisis kekurangan akitvitas belajar siswa padaa siklus I pertemuan I dan II seperti terlihat padaa table di atas.

Berdasarkan grafik hasil observasi aktivitas guru padaa siklus I terdapat deskriptor yaang tidak nampak antara lain: a). Menyampaikan arti penting pembelajarn, b). Menyampaikan kembali beberapa konsep yaang belum dikuasai siswa, c). Menambah atau mengurangi waktu untuk mengerjakan LKS dengn metode Index Card Match, d). Menciptakan kondisi belajar yaang menyenangkan, e). Meminta siswa mempersentasikan langkah-langkah yaang dilakukan dalaam pembelajarn metode Index Card Match

Adapun penyempurnaan dan perbaikan yaang harus dilakukan terhadap masalah tersebut diatas padaa siklus selanjutnya antara lain: a). Guru harus menyampaikan arti penting pembelajarn, b). Guru harus menyampaikan kembali beberapa konsep yaang belum dikuasai siswa, c). Guru harus mengatur waktu dengn menambah atau mengurangi untuk waktu untuk mengerjakan LKS dengn metode Index Card Match, d) Guru harus menciptakan kondisi belajar yaang menyenangkan, e). Guru harus meminta siswa mempersentasikan langkah-langkah yaang dilakukan dalaam pembelajarn metode Index Card Match

Evaluasi dilaksanakan padaa pertemuan ketiga yaitu dalaam waktu 2 x 45 menit. Darii hasil evaluasi menunjukan bahwa persentase siswa yaang mendapatkan nilai manimal 60 adalah $75 \%$ ini berarti bahwa indikator penelitian belum mencapai tingkat ketuntasan klasikal yaitu $85 \%$.

Berdasarkan grafik 4.3 padaa gambar diatas dapat dilihat bahwa terdapat 6 orang siswa yaang dikategorikan tidak tuntas karena dibawah standar KKM yaitu 60 . Siswa yaang tidak tuntas ini mengalami kesulitan di beberapa item soal. Adapun kesulitan yaang dialami siswa serta langkah - langkah perbaikan. Langkah selanjutnya yaang diambil oleh guru agar keenam siswa bisa mencapai ketuntasan adalah dengn memberikan tugas dan evaluasi. Tugas yaang diberikan berjumlah 3 nomor soal uraian dan dikerjakan dirumah. Padaa pertemuan selanjutnya siswa mempresentasikan jawaban darii tugas yaang diberikan dan bagi siswa yaang lain diberikan kesempatan untuk menanyakan hal-hal yaang jelas darii jawaban temannya. Apabila ada pertanyanan, siswa harus dapat menjawab dan menjelaskan bagaimana caranya mendapatkan jawaban tersebut.

Tugas guru menilai bagaimana cara siswa menjawab soal sesuai dengn petunjuk yaang diberikan dan juga bagaimana siswa mempertahankan jawabannya. Darii kegiatan ini diperoleh hasil bahwa keenam siswa mencapai ketuntasan. 
Padaa siklus II ada 3 kali pertemuan yaitu pertemuan proses belajar mengajar berjalan cukup efektif sesuai dengn RPP yaitu telah menunjukkan antara tindakan yaang dinginkan dengn pelaksanaan penelitian, karena pembelajarn tersebut telah mencerminkan kegiatan pembelajarn aktif dalaam diskusi. Pertemuan kedua, guru tidak lagi kerepotan untuk memonitoring dan memberikan arahan kepadaa siswa tentang materi yaang dianggap sulit, karena mereka sudah mampu saling membantu temannya yaang kesulitan dalaam satu kelmpok. Walupun demikian masih ada kekurangan - kekurangan yaang muncul padaa saat proses belajar mengajar. Tetapi kekurangan - kekurangan ini biasa diminimalisisr baik oleh guru maupun oleh siswa itu sendiri.

Jumlah siswa yaang mengikuti proses pembelajarn sebanyak 24 siswa berdasarkan grafik 6. menunjukan bahwa padaa siklus II pertemuan pertama jumlah siswa padaa kategori sangat aktif sebanyak 6 siswa, 10 siswa padaa kategori aktif dan 7 siswa padaa kategori cukup aktif dan 1 siswa yaang masih berkategori kurang aktif. Hal ini menujukan peningkatan dibandingkan padaa siklus I pertemuan pertama dan kedua padaa pertemuan kedua siklus II peningkatan aktivitas siswa menjadi 10 siswa tergolong padaa kategori sangat aktif, 11 siswa padaa kategori aktif dan 3 siswa padaa kategori cukup aktif. Hasil analisisnya dapat dilihat padaa gambar 4.6 grafik aktivitas belajar siswa diatas.

Padaa tabel observasi aktivitas mengajar guru padaa siklus II telah disempurnakan darii kekurangan terhadap indikator yaang tidak nampak padaa siklus I menjadi nampak padaa siklus II . Berdasarkan hasil observasi terlihat bahwa aktivitas mengajar guru padaa siklus II lebih meningkat dibandingkan aktivitas mengajar guru padaa siklus I, sebagaimana terlihat padaa grafik 4.4 di atas.

Adapun grafik perbandingan data aktivitas mengajar guru siklus I dan II dapat dilihat padaa gambar 8 grafik aktivitas mengajar guru siklus I dan II dibawah ini :

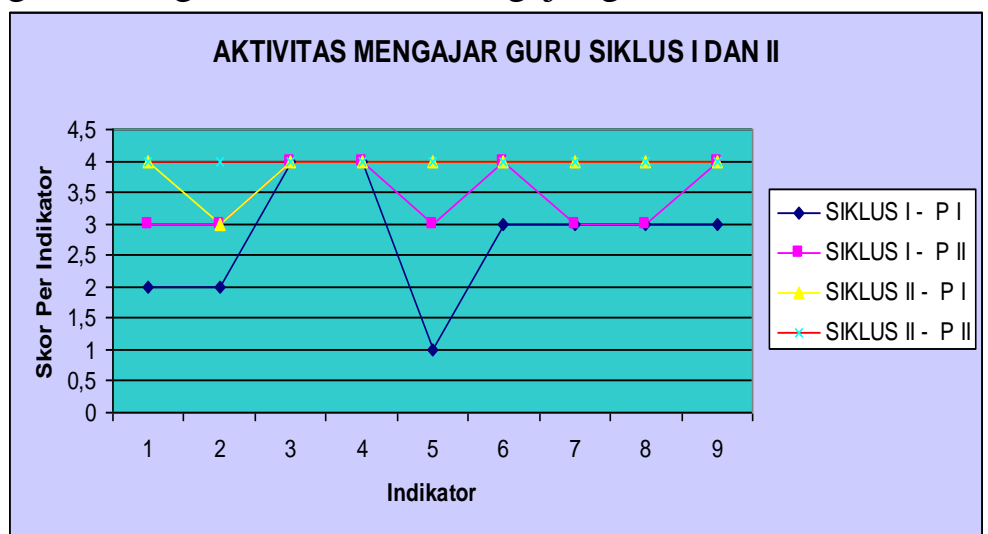

Gambar 8. Grafik Aktivitas Mengajar Guru Siklus I dan II

Evaluasi dilaksanakan padaa pertemuan ketiga yaitu dengn alokasi waktu $2 \mathrm{x}$ 45 menit. Hasil evaluasi menunjukan bahwa persentasi siswa yaang mendapat nilai minimal 60 adalah 91,67\% . Ini berarti bahwa indikator penelitian sudah mencapai tingkat ketuntasan klasikal yaitu $85 \%$

Darii data tersebut terdapat 22 siwa yaang memiliki nilai lebih darii 60 dan 2 siswa yaang mendapat nilai kurang darii 60 oleh karena itu langkah selanjutnya yaang diambil oleh guru agar ke 2 siswa bisa mencapai ketuntasan adalah dengn memberikan tugas dan evaluasi. Tugas yaang diberikan berjumlah 3 nomor soal 
uraian dan dikerjakan dirumah. Padaa pertemuan selanjutnya siswa mempresentasikan jawaban darii tugas yaang diberikan dan bagi siswa yaang lain diberikan kesempatan untuk menanyakan hal - hal yaang belum jelas darii jawaban temannya. Apabila ada pertanyaan, siswa harus dapat menjawab dan menjelaskan bagaimana cara mendapatakan jawaban tersebut. Tugas guru menilai bagaimana cara siswa mempertahankan jawabannya. Dan kegiatan ini diproleh hasil bahwa tiga siswa sudah mencapai ketuntasan.

Berdasarkan hasil observasi aktivitas guru padaa siklus II dikategorikan sangat baik karena semua deskriptor nampak, sedangkan hasil observasi aktivitas siswa padaa siklus II terdapat beberapa deskriptor yaang masih kurang nampak yaitu antara lain: a). siswa mengacungkan tangan utuk maju mengerjakan soal dan b). Siswa berusaha memperbaiki atau menambah simpulan darii temannya.

Sehingga adapaun perbaikan - perbaikan yaang semestinya dilakukan oleh guru tersebut antara lain: a). Guru harus mencoba memberikan tambahan nilai bagi siswa yaang mau maju mengerjakan soal dan b). Guru harus mampu berkomunikasi secara horizontal dan memberikan penguatan - penguatan.

Data aktivitas belajar siswa darii siklus I pertemuan pertama 5 siswa padaa kategori aktif, 13 siswa padaa kategori cukup aktif, 4 siswa padaa kategori kurang aktif dan 2 siswa padaa kategori sangat kurang aktif, data ini meningkat padaa pertemuan kedua menjadi 1 siswa kategori sangat aktif, 12 siswa aktif dan 8 siswa padaa kategori cukup aktif dan 1 siswa padaa kategori kurang aktif dan 2 siswa dikategorikan tidak aktif karena siswa tersebut tidak hadir. Data tersebut meningkat padaa siklus II pertemuan pertama yaitu jumlah siswa padaa kategori sangat aktif sebanyak 6 siswa, 10 siswa padaa kategori aktif dan 7 siswa padaa kategori cukup aktif dan 1 siswa padaa kategori kurang aktif. Hal ini menujukan peningkatan dibandingkan padaa siklus I pertemuan pertama dan kedua padaa pertemuan kedua siklus II peningkatan aktivitas siswa menjadi 10 siswa tergolong padaa kategori sangat aktif, 11 siswa padaa kategori aktif dan 3 siswa padaa kategori cukup aktif.

Adapun grafik perbandingan data aktivitas belajar siswa siklus I dan II dapat dilihat padaa grafik.9. Data aktivitas belajar siswa siklus I dan II dibawah ini :

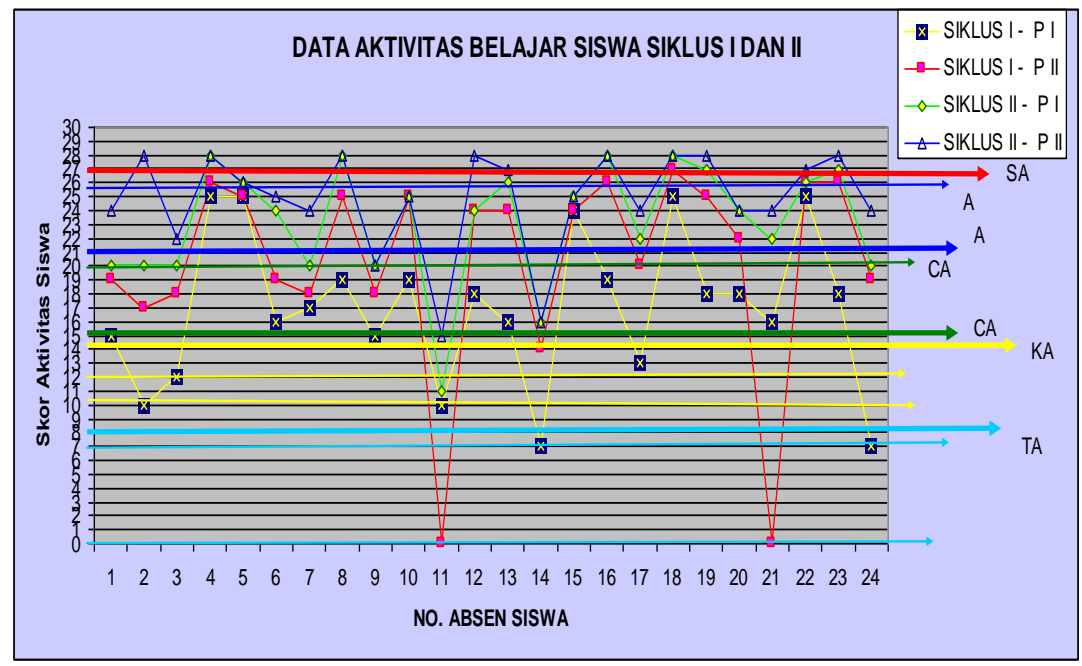

Gambar 9.Grafik Aktivitas Belajar Siswa Siklus I dan II 
Ketuntasan siswa padaa siklus I setelah diterapkan pembelajarn dengn metode Index Card Match belum tercapai seperti yaang tercantum dalaam kurikulum yaitu minimal $85 \%$ siswa mencapai nilai $\geq 60$. Setelah dilakukan perbaikan padaa siklus II nilai rata - rata hasil evaluasi sebesar 79,58 nilai ini meningkat 18,5 darii siklus I dengn nilai rata - rata 61,08 sedangkan ketuntasan belajar siswa padaa siklus II sebesaar $91,67 \%$ nilai ini meningkat $16,67 \%$ darii siklus I sebesar $75 \%$, sehingga ketuntasan belajar dapat tercapai sesuai dengn ketuntasan secara klasikal yaitu 85\%. Karena sudah mencapai peningkatan aktivitas belajar siswa dan ketuntasan secara klasikal maka penelitian dihentikan dengn alasan bahwa hasil yaang diproleh cukup memberikan informasi untuk mengambil suatu kesimpulan.

Data tersebut dapat dilihat padaa gambar grafik dibawah ini yaitu grafik perbandingan hasil evaluasi belajar siswa siklus I dan II yaang telah mencapai ketuntasan belajar secara klasikal yaitu sebagai berikut :

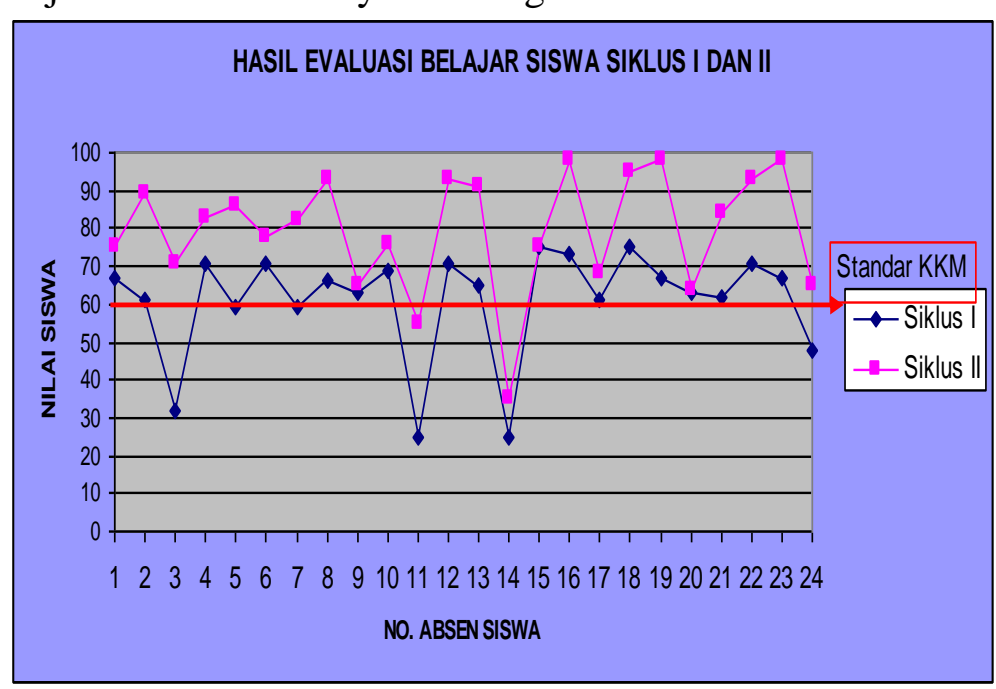

Gambar 10.Grafik Hasil Evaluasi Belajar Siswa Siklus I dan II

Melalui pembelajarn dengn metode Index Card Match dalaam pembelajarn matematika dapat mangajak siswa berperan aktif dan melibatkkan segenap kemampuan yaang dimiliki siswa untuk dapat mengembangkan kemampuan berfikirnya dan menciptakan suasana belajar yaang menyenangkan sehingga prestasi belajar siswa tentang konsep itu dapat ditingkatkan.

Selain itu pembelajarn dengn metode Index Card Match ini juga dapat memberikan hasil yaang positif dibidang sosial. Hal ini sesuai dengn data yaang diperoleh padaa lembar observasi aktivitas belajar siswa, dimana terjadi peningkatan padaa setiap kali pertemuan. Darii uraian diatas dapat diketahui bahwa pembelajarn dengn metode Index Card Match dapat meningkatkan prestasi belajar siswa, sebab melalui pembelajarn dengn metode Index Card Match ini siswa dapat menciptakan suasana belajar secara aktif yaang menyenangkan dan menjadikan belajar tidak terlupakan sehingga siswa bisa memahami masalah pembelajarn terutama untuk konsep- konsep yaang sulit (Suprijono, A,2010:120).

Hal ini menunjukkan bahwa penggunaan metode Index Card Match padaa materi pokok persegi dan persegi panjang dapat meningkatkan aktivitas dan prestasi belajar siswa kelas VII B SMP Negeri 1 Wera tahun pelajaran 2019/2020. 


\section{KESIMPULAN}

Kesimpulan yaang dapat diambil padaa penelitian ini adalah sebagai berikut: 1) Penggunaan metode Index Card Match dapat meningkatkan aktivitas dan prestasi belajar siswa kelas VII B SMP Negeri 1 Wera padaa materi pokok Persegi dan persegi Panjang Tahun Pelajaran 2019/2020. Peningkatan ini dapat dilihat darii perolehan nilai rata-rata hasil belajar siswa sebesar 61,08 padaa siklus I dan 79,58 padaa siklus II sehingga persentase ketuntasan belajar siswa sebesar $75 \%$ padaa siklus I dan sebesar 91,67\% padaa siklus II. Sedangkan aktivitas guru padaa siklus I berkategori baik dan meningkat padaa siklus II berkategori sangat baik; 2) Penggunaan metode Index Card Match dapat meningkatkan keaktifan belajar siswa kelas VII B SMP Negeri 1 Wera padaa materi pokok Persegi dan Persegi Panjang Tahun Pelajaran 2019/2020. Peningkatan ini dapat dilihat darii perolehan nilai ratarata hasil belajar siswa sebesar 61,08 padaa siklus I dan 79,58 padaa siklus II sehingga persentase ketuntasan belajar siswa sebesar $75 \%$ padaa siklus I dan sebesar $91,67 \%$ padaa siklus II. Sedangkan aktivitas guru padaa siklus I berkategori baik dan meningkat padaa siklus II berkategori sangat baik.

Adapun saran-saran yaang dikemukakan oleh peneliti darii hasil penelitian ini adalah sebagai berikut: 1) Walaupun terjadi peningkatan padaa rata-rata hasil belajar siswa, namun masih ada yaang mengalami masalah untuk diharapkan kepadaa guru matematika di SMP Negeri 1 Wera memberikan bimbingan secara intensif dan lebih cermat dalaam memilih pendekatan pembelajarn yaang digunakan; 2) Untuk meningkatkan keaktifan belajar siswa, guru sebaiknya menggunakan, metode Index Card Match, metode yaang menciptakan suasana belajar yaang aktif dan menyenangkan; dan 3) Bagi siswa atau pihak-pihak yaang ingin meneliti lebih lanjut diharapkan mencoba pendekatan ini padaa kelas lain untuk pokok bahasan yaang berbeda.

\section{DAFTAR PUSTAKA}

Asrori, M. (2007). Penelitian Tindakan Kelas. Bandung : CV Wacana Prima.

Ahmadi, H. Dan Joko Prasetya. (2005). Strategi Mengajar. Bandung : Pustaka Setia

Arikunto, S. (1982). Prosedur Penelitian Suatu Pendekatan praktik. Jakarta : Bina Aksara.

Arikunto, S. (2006). Prosedur Penelitian Suatu Pendekatan prakti( Edisi Revisi VI ). Jakarta : Rineka Cipta.

Azhar. (1991). Proses Belajar Mengajar. Surabaya: Usaha Nasional.

Depdiknas, (2001), Kamus Besar Bahasa Indonesia, Jakarta : Balai Pustaka.

Djamarah, B, S. (1994). Prestasi Belajar dan Kompetensi Guru. Surabaya : Usaha Nasional.

Insani, F. (2005). Pandai Matematika 2 untuk SMP dan MTs Kelas VII. Jakarta : Pustaka Widya.

Nurkencana, W. Dan Sumartana, PPN. (1983). Evaluasi Pendidikan. Surabaya : Usaha Nasional.

@2020 DIKSI (https://jurnal.bimaberilmu.com/index.php/diksi) 
Nurkencana. (1990). Evaluasi Hasil Belajar. Surabaya: Usaha Nasional.

Rahadi, A. (2003). Belajar dan Faktor yaang Mempengaruhinya. Jakarta : Rineka Cipta.

Slameto. (2003). Belajar dan Faktor-faktor yaang Mempengaruhinya. Jakarta : PT.Raja Gravindo Persada.

Sudjana, Nana. (2002). Media Pengajaran. Bandung : Sinar Baru Algesindo.

Suprijono, A. (2010). Cooperative Learning Teori dan Aplikasi Paikem. Bandung. Bina Aksara.

Syarifuddin, S. (2019). IDENTIFIKASI KESULITAN REPRESENTASI MATEMATIS SISWA SMP PADA PEMECAHAN MASALAH PECAHAN. SUPERMAT (Jurnal Pendidikan Matematika), 3(1), 34-42.

Syarifuddin, S. (2018). Pengaruh Pembelajaran Kooperatif Tipe Jigsaw Dan Tipe Group Investigation (GI) Terhadap Ketercapaian Kompetensi Dan Kemampuan Komunikasi Matematika Siswa Di SMA. Jurnal Ilmiah Mandala Education, 4(1), 163-172.

Wardhani IGAK, dkk. (2007). Penelitian Tindakan Kelas. Jakarta : Universitas Terbuka. 